Terbit online pada laman web jurnal: http://jurnal.iaii.or.id

\begin{tabular}{c} 
JURNAI R RS'I \\
(IAll \\
$\begin{array}{l}\text { (Rekayasa Sistem dan Teknologi Informasi) } \\
\text { Vol.5 No.4 (2021) } 647-655\end{array}$ \\
\hline
\end{tabular}

\title{
Realtime Object Detection Masa Siap Panen Tanaman Sayuran Berbasis Mobile Android Dengan Deep Learning
}

\author{
Andri Heru Saputra ${ }^{1}$, Dhomas Hatta Fudholi ${ }^{2}$ \\ ${ }^{1}$ Program Studi Informatika Program Magister, Teknologi Industri, Universitas Islam Indonesia \\ ${ }^{2}$ Jurusan Informatika, Teknologi Industri, Universitas Islam Indonesia \\ 118917206@students.uii.ac.id, ${ }^{2}$ hatta.fudholi@uii.ac.id*
}

\begin{abstract}
Determining the harvesting period can be done visually, physically, computationally, and chemically. Since the harvesting process is crucial, late harvesting will affect post-harvest and production quality. Leafy vegetables have a relatively short ready-to-harvest period. Visual recognition of the harvesting period combined with image processing can recognize harvesting vegetables' visual characteristics. This study aims to build a deep learning-based mobile model to detect real-time vegetable plant objects such as bok choy, spinach, kale, and curly kale to determine whether these vegetables are ready for harvest. Mobile-based architecture is chosen due to latency, privacy, connectivity, and power consumption reason since there is no round-trip communication to the server. In this research, we use MobileNetV3 as the base architecture. To find the best model, we experiment using different image input size. We have obtained a maximum MAP score of 0.705510 using a 36,000 image dataset. Furthermore, after implementing the model into the Android mobile application, we analyze the best practice in using the application to capture distance. In real-time detection usage, the detection can be done with an ideal distance of $5 \mathrm{~cm}$ and $10 \mathrm{~cm}$.
\end{abstract}

Keywords: real-time, object detection, vegetable, harvest, MobileNetV3

\begin{abstract}
Abstrak
Penentuan masa panen dapat dilakukan secara visual, fisik, komputasi, dan kimiawi. Karena proses pemanenan sangat penting, pemanenan yang terlambat akan mempengaruhi pascapanen dan kualitas produksi. Sayuran berdaun memiliki masa siap panen yang relatif singkat. Pengenalan visual masa panen yang dikombinasikan dengan pengolahan citra dapat mengenali karakteristik visual panen sayuran. Penelitian ini bertujuan membangun model ponsel berbasis deep learning untuk mendeteksi objek tanaman sayuran secara real-time seperti pakcoy, bayam, kangkung, dan kale keriting untuk mengetahui apakah sayuran tersebut siap dipanen. Arsitektur berbasis seluler dipilih karena alasan latensi, privasi, konektivitas, dan konsumsi daya karena tidak ada komunikasi bolak-balik ke server. Dalam penelitian ini, kami menggunakan MobileNetV3 sebagai arsitektur dasarnya. Untuk menemukan model terbaik, kami bereksperimen menggunakan ukuran input gambar yang berbeda. Kami telah memperoleh skor MAP maksimum 0,705510 menggunakan 36.000 dataset gambar. Selanjutnya, setelah mengimplementasikan model ke dalam aplikasi seluler Android, kami menganalisis praktik terbaik dalam menggunakan aplikasi untuk menangkap jarak. Dalam penggunaan deteksi real-time, pendeteksian dapat dilakukan dengan jarak ideal $5 \mathrm{~cm}$ dan $10 \mathrm{~cm}$.
\end{abstract}

Kata kunci: real-time, deteksi objek, sayuran, panen, MobileNetV3

\section{Pendahuluan}

Panen dan pasca panen merupakan proses yang tidak dapat dipisahkan dalam pertanian. Panen merupakan rangkaian kegiatan pengambilan hasil budidaya berdasarkan umur dan waktu, dengan cara yang sesuai sifat dan/atau karakter produk. Pasca panen adalah kegiatan yang dilakukan setelah pemanenan agar hasil pertanian siap dan aman untuk diolah oleh lembaga industri atau konsumen [1].
Menentukan waktu panen yang tepat, waktu menentukan "kematangan" yang tepat dan saat panen yang sesuai dapat dilakukan berbagai cara dan pendekatan, yaitu visual, fisik, analisis kimia, dan komputasi atau perhitungan. Secara umum, pertanian sayuran menggunakan komputasi, visual dan fisik dalam memanen sayuran dengan cara memberikan label tanggal pembibitan hingga waktu yang siap dipanen. Kriteria panen dengan cara visual biasanya melihat tanaman sayuran dari perubahan warna, perubahan

Diterima Redaksi: 06-06-2021 | Selesai Revisi: 05-08-2021 | Diterbitkan Online: 20-08-2021 
bentuk dan ukuran, daun-daun mulai mengering dan buah sudah berkembang penuh.

Tanaman sayuran daun yang ditanam dengan cara hidroponik memiliki waktu panen yang relatif singkat. Tanaman sayuran kale keriting (selanjutnya akan disebut dengan kale saja) memiliki masa panen 55 hari [2], tanaman sayuran kangkung memiliki masa panen 21-30 hari [3], tanaman sayuran bayam memiliki masa panen 25-30 hari [3], tanaman sayuran pakcoy memiliki masa panen 45 hari [3]. Masa panen dapat diperhatikan dari ciri visual perubahan bentuk, warna dan ukuran pada tanaman sayuran daun. Pakcoy memiliki ciri visual masa panen yaitu daun berwarna hijau segar, daun lebar memiliki ukuran 9-15 cm [6], dan batang tanaman keras atau tegak. Masa siap panen kangkung memiliki ciri visual daun sedikit lebar memanjang berwarna hijau segar dan batang tanaman memiliki panjang 20-25 cm [7]. Bayam memiliki ciri visual masa panen daun berwarna hijau segar, lebar daun sedikit besar, dan tinggi tanaman 15-20 cm serta belum berbunga [13]. Tanaman sayuran kale memiliki ciri visual masa panen seperti warna daun hijau segar dan dipinggir daun bergelombang banyak atau keriting, serta ukuran daun lebar memanjang.

Melihat ciri visual yang ada pada tanaman penelitianpenelitian Artificial Intelligence (AI) pada bidang pertanian yang membantu dalam proses pengelolaan pertanian. Pengolahan citra di bidang pertanian pada penelitian [4] mendeteksi tingkat kemanisan buah penan Support Vector Machine (SVM) berdasarkan data memilih model yang paling sesuai dengan tugas deteksi warna. Penelitian ini menggunakan 24 objek dan penyakit tomat, empat jaringan neural konvolusional menghasilkan akurasi KNN dan SVM sebesar 83,3\% dalam yang berbeda digabungkan dengan dua model dan $87,5 \%$. Mendeteksi kecacatan pada buah manggis deteksi objek. Hasil percobaan menunjukkan bahwa dengan CNN dilakukan pada [5] dengan hasil rata-rata model yang diusulkan dapat secara akurat dan cepat akurasi yang diperoleh sebesar 98\%. Penelitian mengidentifikasi sebelas jenis penyakit tomat dan berikutnya mengenai mengidentifikasi kematangan menyegmentasikan lokasi dan bentuk daerah yang mentimun berdasarkan tekstur kulit [8]. Metode yang terinfeksi [18].

dipakai adalah metode statistik Mean, Variance, Skewness, Kurtosis dan Entropy yang menghasilkan akurasi prediksi $75 \%$ dengan 20 citra [8]. Penelitian yang dilakukan [9] mendeteksi tingkat kematangan tomat berdasarkan warna Hue Intensity Saturation (HIS) dan memperoleh akurasi sebesar 94,28\%.

Penelitian [10] mendeteksi kematangan buah salak pondoh yang di pohon dengan menggunakan backpropagation dan algoritma KNN. Sistem yang dibangun dapat mendeteksi kematangan salak pondoh di pohon berdasarkan warna Red Green Blue (RGB) dan Hue Saturation Value (HSV) dengan tingkat akurasi
sebesar 93\%. Penelitian [11] mendeteksi buah yaitu buah paprika dengan menggunakan faster R-CNN. Data multi-modal (RGB dan Near-Infrared (NIR) digunakan pada penelitian ini yang dapat menghasilkan skor F1 0,838 .
Penelitian [12] mengenal kematangan daun selada warna RGB. Penelitian mengenai deteksi vegetasi dan diskriminasi dalam sayuran plasticulture row - middles biasa ditemukan di tengah-tengah baris plastik budidaya tanaman Florida (jaringan kelas 3). Vegetasi dibedakan menjadi tiga kategori: daun lebar, alang-alang dan Jaringan 3-kelas (Fscore = 0,95) mengungguli jaringan 1-kelas (Fscore $=0,93$ ) secara keseluruhan deteksi vegetasi. Penelitian selanjutnya engenai penggunaan Algoritma YOLOv3 dengan PrePasca-Pemrosesan untuk deteksi buah apel di robot kesalahan obyek yang dianggap apel $7,8 \%$ dan bagian

deteksi buah menggunakan peningkatan berdasarkan segmentasi warna. Peneltian berikutnya menggunakan Red Green Blue - Depth (RGB-D) dan CNN untuk menilai buah dan sayuran berdasarkan Penelitian [18] mengembangkan metode deteksi penyakit tomat berbasis jaringan saraf konvolusional dalam dan model deteksi objek. Dua model berbeda, Faster R-CNN dan Mask R-CNN, digunakan dalam metode ini, dimana Faster R-CNN digunakan untuk mengidentifikasi jenis penyakit tomat dan Mask R-CNN Penelitian [19] menggunakan deep learning CNN dalam mengklasifikasikan sayuran, dengan hasil akurasi 98,1\%. Penelitian [20] mengenai kondisi kematangan buah jeruk berdasarkan kemiripan warna pada ruang warna RGB berbasis android, aplikasi mampu mengenali kondisi kematangan buah jeruk keprok. Masing-masing 2 buah jeruk pada kondisi matang dengan nilai kesesuaian antara 72,94\% sampai $82,68 \%$. Selanjutnya 4 buah jeruk pada kondisi mengkal dengan nilai kesesuaian antara 59,09\% sampai $81,20 \%$ serta 4 buah jeruk pada kondisi mentah dengan nilai kesesuaian antara 69,02\% sampai 77,60\% [20].

Penelitian mengenai aplikasi deteksi kematangan buah sawit menggunakan metode perbandingan histogram citra, dengan file ekstensi gambar buah sawit berupa bitmap dan aplikasi Matlab R2010a sebagai imageprocessing [21]. Hasil eksperimen dari pengujian aplikasi menunjukkan tingkat akurasi yang baik yaitu menggunakan OpenCV berbasis Android berdasarkan apel yang tidak dikenali $9,8 \%$.

DOI: https://doi.org/10.29207/resti.v5i4.3190

Lisensi: Creative Commons Attribution 4.0 International (CC BY 4.0) 
$80 \%$ untuk pengujian pada buah sawit belum siap panen sedangkan pada buah sawit siap panen juga menunjukan tingkat akurasi sama yaitu $80 \%$ [21].

Penelitian selanjutnya mengenai deteksi kematangan buah pisang berdasarkan fitur warna citra kulit pisang ambon menggunakan metode transformasi ruang warna HIS, dalam penelitianya membahas transformasi dari warna RGB menjadi HIS sehingga hasil penelitian dengan pengujian 20 sampel buah dimana 10 buah pisang ambon mentah dan 10 buah pisang ambon matang dengan dihitung nilai rata-rata maksimal dan minimal $\mathrm{H}$ dan $\mathrm{S}$ diperoleh akurasi kesesuaian sebesar $85 \%$ [22]. Penelitian mengenai deteksi kematangan buah semangka berbasis nilai RGB menggunakan metode thresholding [23].

Penelitian mengenai deteksi tanaman tebu pada lahan pertanian menggunakan metode $\mathrm{CNN}$ [24] dengan menggunakan drone dan menggunakan YOLO mampu menghasilkan penelitian menunjukkan bahwa metode CNN berhasil untuk mendeteksi tebu dengan baik dengan menghasilkan rata-rata nilai confidence sebesar 95\% pada pengujian video. Pengujian menggunakan pada nilai threshold 0.1 , menghasilkan skor precision sebesar 1.00, skor recall sebesar 0.95 dan skor accuracy sebesar 0.95 pada tebu [24]. Penelitian dengan klasifikasi citra buah menggunakan CNN dengan menggunakan dataset Fruit-360 [25]. Hasil dari proses learning didapatkan model CNN dengan akurasi $100 \%$ dan loss sebesar 0,012. Pada proses pengujian model CNN yang mengguakan 45 sampel citra buah didapatkan akurasi sebesar $91,42 \%$. Sehingga dapat disimpulkan bahwa metode CNN yang dirancang pada penelitian ini dapat mengklasifikasi citra dengan baik [25].

Pada penelitian ini, kami bertujuan memanfaatkan AI lebih jauh lagi pada bidang pertanian dengan membangun sebuah model object detection untuk deteksi masa panen (siap panen atau belum siap panen) tanaman sayuran. Model dibangun dengan arsitektur mobile yang mengedepankan faktor latency, privacy, connectivity, dan power consumption, karena model berjalan pada perangkat bergerak tanpa harus ada komunikasi dengan server. Penelitian ini menggunakan data tanaman sayuran kangkung, bayam, kale, dan pakcoy. Sumber data tanaman sayuran diperoleh dari PT. Indmira. Basis arsitektur yang dipakai pada pengembangan model ini adalah SSD MobileNetV3. Evaluasi dari model yang dibangun adalah dengan menggunakan skor Mean Average Precision (MAP) yang mengukur tingkat akurasi prediksi mengenai deteksi objek kemudian model diimplementasikan ke dalam mobile. Mobile yang digunakan adalah berbasis android, pemilihan android dikarenakan android merupakan sistem operasi yang mampu berjalan secara mobile, alasan lain karena sistem operasi android banyak digemari oleh masyarakat karena sifatnya yang open source.

\section{Metode Penelitian}

Metodologi penelitian yang digunakan untuk penelitian realtime object detection masa siap panen tanaman sayuran meliputi pengumpulan data berupa gambar tanaman sayuran, pelabelan dan validasi data, pembangunan model, implementasi dan pengujian serta evaluasi. Alur dalam metode penelitian realtime object detection masa siap panen tanaman sayuran seperti Gambar 1.

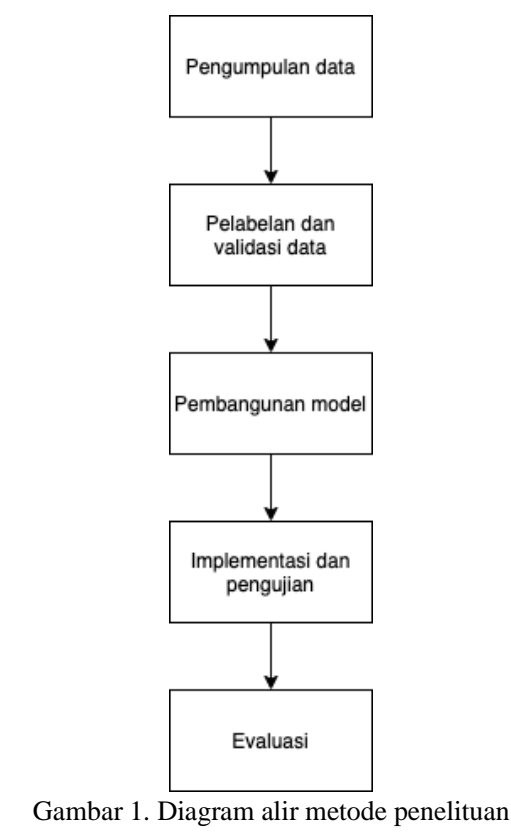

Pengumpalan data gambar adalah gambar tanaman sayuran dengan resolusi 2304 x 4608 dan ekstensi jpg kemudian dilakukan prepocessing data seperti menyortir gambar yang tidak sesuai dalam penelitian dan mengubah ukuran resolusi gambar menjadi 512 x 1024 . Dari hasil prepocessing, data gambar diberi label dengan tools LabelImg. Data gambar yang sudah diberikan label kemudian divalidasi oleh ahli pertanian tanaman sayuran, yaitu praktisi tenaga pengajar yang mempelajari tanaman sayuran selama 6 tahun terakhir.

Dalam pembangunan model, pada penelitian objek deteksi masa siap panen tanaman sayuran diperlukan pelatihan model yaitu menggunakan Tensorflow 1.15 GPU dengan konfigurasi SSD Mobilenet v3 large untuk paket object detection. Pelatihan model dilakukan dengan membandingkan input dengan image resizer 320 x 320,512 x 512, 640 x 640 dan 1024 x 1024, dan evaluasi model untuk mengetahui skor MAP yang menunjukkan tingakt akurasi dalam memprediksi objek. Nilai MAP menunjukkan tingkat akurasi deteksi objek dan letaknya. Nilai ini menjadi parameter utama untuk mengukur akurasi suatu model yang diaplikasikan dan seberapa bagus model tersebut untuk menangani objek tanpa ada kesalahan. Semakin tinggi nilai MAP, semakin tinggi pula akurasi yang didapat, namun sebagai konsekuensinya, kecepatan komputasi menjadi lebih 
rendah [20]. Perhitungan akurasi untuk mengetahui nilai siap panen, tanaman kangkung yang belum dan yang tingkat akurasi dalam mendeteksi tanaman sayuran siap panen, dan tanaman kangkung yang belum dan yang dengan menggunakan persamaan (1).

$$
m A P=\frac{1}{N} \sum_{j=1}^{N} \frac{1}{Q j} \sum_{i=1}^{Q j} P\left(d o c_{i}\right)
$$

dengan Qj adalah banyaknya dokumen relevan untuk query $\mathrm{j}, \mathrm{N}$ adalah banyaknya query, dan $\mathrm{P}($ doci) adalah precision pada dokumen relevan ke-i.

Setalah melakukan evaluasi model adalah mengimplementasikan model tersebut ke dalam aplikasi android. Aplikasi yang sudah terbangun diuji dengan cara realtime. Skenario pengujian aplikasi deteksi masa siap panen pada tanaman sayuran dengan skenario jarak antara ponsel android dan gambar tanaman sayuran, jarak yang digunakan adalah $5 \mathrm{~cm}, 10 \mathrm{~cm}, 15 \mathrm{~cm}$, dan 20 $\mathrm{cm}$ di mana dari jarak tersebut mendeteksi gambar tanaman sayuran dengan cara realtime. Setelah pengujian selesai dilakukan perhitungan mengenai tingkat akurasi dalam mendeteksi masa siap panen (belum atau siap panen) tanaman sayuran. Dalam menghitung tingkat akurasi menggunakan persamaan (2).

$$
\text { akurasi }=\frac{(T P+T N)}{T P+T N+F P+F N}
$$

Keterangan:

True Positive $(\mathrm{TP})=$ Keterangan hasil prediksi tanaman sesuai dengan keterangan tanaman informasi gambar dan keterangan masa siap panen sesuai dengan keterangan masa siap panen informasi gambar.

True Negative $(\mathrm{TN})=$ Keterangan hasil prediksi tanaman tidak sesuai dengan keteranagan tanaman informasi gambar dan keterangan masa siap panen tidak sesuai dengan keterangan masa siap informasi gambar.

False Positive (FP) = Keterangan hasil prediksi tanaman sesuai dengan keterangan tanaman informasi gambar dan keterangan masa siap panen tidak sesuai dengan keterangan masa siap panen informasi gambar.

False Negative $(\mathrm{FN})=$ Keterangan hasil prediksi tanaman tidak sesuai dengan keterangan tanaman informasi gambar dan keterangan hasil prediksi masa panen sesuai dengan keterangan masa siap panen informasi gambar.

\section{Hasil dan Pembahasan}

Bagian ini akan dijelaskan hasil dan pembahasan dari proses penenlitian yang sudah dilakukan melalui tahapan demi tahapan.

\subsection{Data Collection dan Preparation}

Data yang diperoleh dari PT. Indmira dengan cara mengambil gambar tanaman sayuran dengan kamera ponsel android VIVO v7 sebanyak 44.000 gambar dengan resolusi 2304 x 4608. Gambar tanaman sayuran yang dikumpulkan adalah tanaman bayam yang belum an yang siap panen, tanaman kale yang belum dan yang siap panen (kalau dari ukuran mulai dari kecil hingga besar). Waktu pengambilan gambar dilakukan pagi hari pukul 08:00 hingga pukul 10:00 supaya gambar tanaman yang diambil adalah tanaman sayuran yang segar bukan yang layu.

Data yang terkumpul sebanyak 44.000 gambar kemudian dilakukan prepocesing data dengan cara yaitu menyortir gambar dan mengubah ukuran resolusi gambar. Prepocesing data dilakukan supaya data yang digunakan sesuai dengan yang akan diteliti. Penyortiran gambar, gambar yang tidak sesuai dengan kebutuhan maka gambar tidak digunakan dengan cara dihapus. Data gambar yang telah disortir menjadi 40.000 gambar. Langkah selanjutnya adalah mengubah ukuran resolusi gambar. Perubahan ukuran resolusi yang semula dari 2304 x 46308 menjadi 512 x 1024 supaya dalam proses pelatihan model tidak memakan waktu lama. Hasil dari prepocesing data kemudian diberikan label dengan tools LabelImg. LabelImg adalah tools yang digunakan untuk melabel sebuah gambar dengan cara memberikan kotak ke daerah atau area yang akan ditandai sebagai temapt label. Format penyimpanan dari labelImg adalah xml. Pada pelabelan gambar terhadap gambar yang dikumpulkan ada gambar yang memiliki informasi sesuai ciri visual masa panen belum siap panen dan siap panen, ada juga dalam satu gambar itu berisikan belum siap panen saja atau siap panen saja. Format penulisan label yang digunakan adalah nama objek_jenis masa siap panen contoh bayam_belum_siap_panen. Proses pelabelan ini dibantu oleh ahli dalam tanaman sayuran untuk memvalidasi apakah hasil pelabelan sudah sesuai atau belum. Data gambar yang sudah tervaliadasi dibagi menjadi data latih dan data uji. Total data yang sudah dibersihkan dan terlabel adalah 40.000, data latih 36.000 data dan data uji 4.000 data.

\subsection{Pelatihan Model dan Evaluasi Model}

Pelatihan model digunakan untuk melakukan ekstrak fitur sehingga komputer mampu mengenali setiap fitur gambar yang sudah terlabeli sebelumnya. Pelatihan model, peneliti menggunakan laptop HP Pavilion dengan spesifikasi core i7 9750h, RAM 16 GB dan GPU NVIDIA GTX-1660Ti 6 GB DDR6 dan framework tensorflow dengan versi 1.15 gpu. Dengan SSD Mobilenet v3 large konfigurasi dalam penelitian ini sebagai berikut:

Tabel 2. Konfigurasi SSD Mobilenet v3 Large

\begin{tabular}{lllll}
\hline No & Image resizer & Num class & Batch size & Num step \\
\hline 1 & $320 \times 320$ & 8 & 16 & 50.000 \\
2 & $512 \times 512$ & 8 & 16 & 50.000 \\
3 & $640 \times 640$ & 8 & 16 & 50.000 \\
4 & $1024 \times 1024$ & 8 & 16 & 50.000 \\
\hline
\end{tabular}

Tabel 2 terdapat informasi yaitu image resizer, num class, batch size, dan num step. Image resizer merupakan yang memiliki ukuran gambar yang akan dirubah 
menjadi ukuran 320 × 320, 512 × 512, 640 × 640 dan Model yang sudah dilatih di generate ke dalam tflite. 1024 x 1024, jadi dari ukuran gambar 512 x 1024 Hasil generate tersebut digunakan dalam pengembangan menjadi 320 × 320, 512 × 512, 640 × 640 dan 1024 x aplikasi android. Metode perancangan aplikasi android 1024 sebagai input dalam ekstrak fitur. Num class adalah yang digunakan adalah metode prototype, metode jumlah kelas atau kategori yang akan diteliti, dalam tersebut sangat cocok dikarenakan aplikasi mengadopsi kasus ini peneliti menggunkan delapan kategori yaitu dari TensorFlow Lite dan lebih cepat penyelesaiannya bayam belum siap panen, bayam siap panen, kangkung tinggal uji dengan model sesuai kebutuhan dan apabila belum siap panen, kangkung siap panen, pakcoy belum pengujiannya kurang sesuai bisa melakukan evaluasi siap panen, pakcoy siap panen, kale belum siap panen, dengan cara mengganti model yang sudah dilatih dan kale siap panen. Batch size merupakan jumlah terlebih dulu kemudian dilakukan pengujian ulang untuk sampel data yang disebarkan ke neural network, peneliti mendapatkan hasil yang sesuai. Dengan mengadopsi menggunakn 16 dengan jumlah data 36.000 gambar Tensorflow lite, file hasil generate tersebut dimasukkan maka algoritma ini akan menggunakan 16 sempel data atau sebagai pengganti file bawaan dari tensorflow lite. pertama dari 36.000 data yang dimiliki kemudian Pengembangan dari TensorFlow Lite sesuai dengan disebarkankan atau dilatih oleh neural network sampai kebutuhan penelitian ini seperti realtime detection, selesai kemudian mengambil kembali 16 sampel data import from gallery, dan captured. Berikut Gambar 3 kedua dari 36.000 data, dan begitu seterusnya sampai 16 tampilan interface aplikasi object detection masa siap sampel data ke 2.250 (36.000 / 16 =2250). Num step panen tanaman sayuran dan Gambar 4 merupakan hasil adalah jumlah step yang dilakukan dalam pelatihan mendeteksi objek tanaman sayuran secara realtime.

model, jumlah yang digunakan untuk penelitian ini adalah 50.000. Dengan perangkat tersebut untuk melakukan pelatihan model dengan 4 konfigurasi tersebut dibutuhkan waktu 25 hari.

Hal selanjutnya yang dilakukan setelah melakukan pelatihan model adalah melakukan evaluasi model. Evaluasi model ini bertujuan untuk mengetahui jumlah keakurasian prediksi dalam deteksi objek. Hasil evaluasi dari pelatihan model digunakan ke tahap selanjutnya yaitu ekspor model dan konversi ke tflite. Gambar 2 merupakan hasil dari evaluasi dengan menjelaskan mAP untuk mengetahui akurasinya dalam pendeteksian objek dengan data uji 4.000 data.

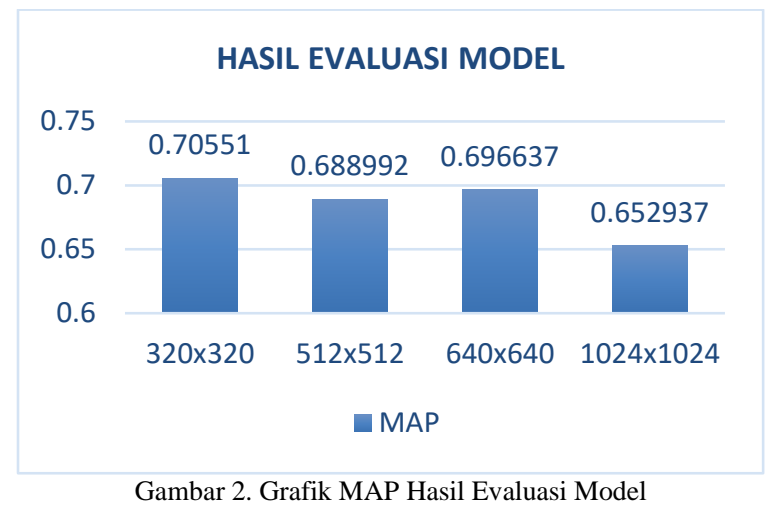

Gambar 2 menunjukan MAP yang tertinggi adalah dengan image resizer 320 × 320 sedangkan MAP paling rendah dari keempat dalam pelatihan model adalah dengan image resizer 1024 x 1024. Semakin MAP tinggi maka semakin bagus dalam memprediksi deteksi objek.

\subsection{Pengembangan Aplikasi Android}

Pengembangan aplikasi android dilakukan setelah melakukan pelatihan model dan evaluasi model. Evaluasi model yang telah dilakukan jadi tahu tingkat keakurasian yang ditunjukkan dengan MAP score.

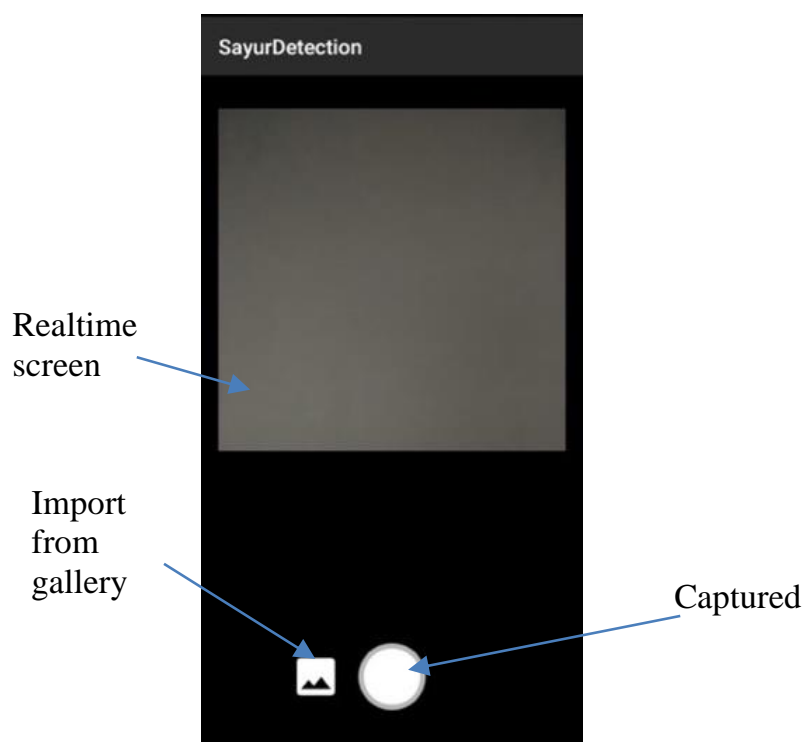

Gambar 3. Interface Aplikasi Android

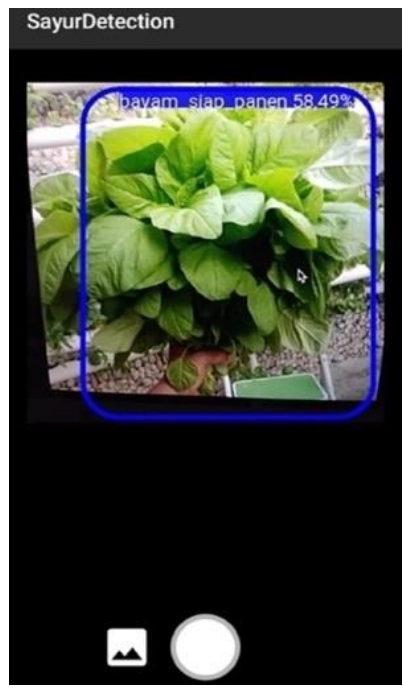

Gambar 4. Hasil Deteksi Tanaman Sayuran Dengan Aplikasi

DOI: https://doi.org/10.29207/resti.v5i4.3190

Lisensi: Creative Commons Attribution 4.0 International (CC BY 4.0) 
Cara kerja aplikasi android deteksi siap panen yaitu melakukan pengujian aplikasi android kemudian dengan cara memindai dengan kamera ponsel android menghitung tingkat akurasi.

melalui aplikasi yang dibangun dengan langsung didapatkan keterangan prediksi hasil pindai selain itu bisa melakukan dengan melakukan ambil dari galeri foto (import from gallery) kemudian keternagan prediksi akan muncul dan apabila ingin mengambil gambar hasil deteksi dengan cara capture. Gambar 4 menjelaskan hasil deteksi tanaman yang memberikan keterangan jenis tanamannya dan prediksi siap panen beserta presentase tingkat akurasinya. Dengan keterangan tersebut bisa diketahui tanaman belum atau siap panen sehingga petani atau pemakai aplikasi ini dapat mengambil tindakan selanjutnya jika sudah siap panen maka hal yang dilakukan adalah persiapan pasca panen sedangkan kalau belum siap panen berarti masih menunggu menuju siap panen. Aplikasi yang sudah siap kemudian dilakukan pengujian untuk memastikan yang terdeteksi itu sesuai atau belum sesuai dengan kenyataan di lapangan. Apabila belum sesuai dilakukan pengecekan terhadap data yang sudah diberikan label dan mengulangi pelatihan model hingga pembangunan aplikasi, jika sudah sesuai maka dilakukan mem-publish aplikasi.

\subsection{Pengujian}

Dalam pengujian ini, peneliti memiliki skenario pengujian yaitu menguji objek dari beberapa jarak antara objek dengan kamera handphone android dengan aplikasi deteksi masa siap panen seperti $5 \mathrm{~cm}, 10 \mathrm{~cm}, 15$ $\mathrm{cm}$, dan $20 \mathrm{~cm}$ mengamati langsung dari aplikasi android dengan kamera atau bisa disebut secara realtime. Pengujian aplikasi menggunakan handphone POCO M3. Dengan menguji berdasarkan jarak dapat diketahui jarak ideal dalam mendeteksi secara realtime itu dapat diketahui apakah dalam mendeteksi tanaman sayuran secara realtime dari berbagai jarak antara objek dengan kamera ponsel android bisa terdeteksi tanamannya dan keterangan masa panen. Gambar 5 merupakan ilustrasi pengujian aplikasi dalam mendeteksi masa siap panen pada tanaman sayuran.

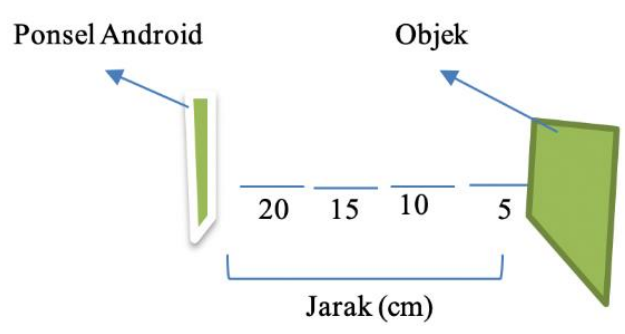

Gambar 5. Ilustrasi Pengujian Aplikasi

Ilustrasi yang tergambar Gambar 5 terdiri dari objek, jarak dan handphone android. Objek yang Gambar 5 berupa gambar tanaman sayuran yang akan dideteksi, jarak pengujian adalah $5 \mathrm{~cm}, 10 \mathrm{~cm}, 15 \mathrm{~cm}$ dan $20 \mathrm{~cm}$, handphone yang digunakan adalah POCO M3. Setelah
Tabel 3 merupakan referensi keterangan kelas untuk klasifikasi yang terdiri dari kode dan keterangan. Kode pada Tabel 3 berupa huruf A sampai $H$ yang akan digunakan Tabel 4 dan Tabel 5.

Tabel 3. Singkatan Keterangan Gambar

\begin{tabular}{ll}
\hline kode & Keterangan \\
\hline A & Bayam_belum_siap_panen \\
B & Bayam_siap_panen \\
C & Kangkung_belum_siap_panen \\
D & Kangkung_siap_panen \\
E & Kale_belum_siap_panen \\
F & Kale_siap_panen \\
G & Pakcoy_belum_siap_panen \\
H & Pakcoy_siap_panen \\
\hline
\end{tabular}

Pengujian dengan 20 gambar terdiri dari keempat jenis tanaman sayuran yaitu bayam, kale, kangkung, dan pakcoy yang akan diuji dengan aplikasi android deteksi masa siap panen. Data pengujian 20 gambar tersaji pada Tabel 4 yang memberikan informasi dengan kode sesuai dengan Tabel 3. Gambar yang digunakan untuk pengujian ini belum terlabel sehingga dalam pengujian aplikasi android diharapkan mampu mendeteksi masa siap panen pada gambar tersebut.

\begin{tabular}{lll} 
& & Tabel 4. Data Pengujian \\
\hline No. & Gambar & Informasi gambar (kode) \\
\hline 1 & Bayam 1 & A \\
2 & Bayam 2 & A \\
3 & Bayam 3 & A \\
4 & Bayam 4 & B \\
5 & Bayam 5 & B \\
6 & Kangkung 1 & D \\
7 & Kangkung 2 & C \\
8 & Kangkung 3 & C \\
9 & Kangkung 4 & C \\
10 & Kangkung 5 & D \\
11 & Pakcoy 1 & H \\
12 & Pakcoy 2 & G \\
13 & Pakcoy 3 & G \\
14 & Pakcoy 4 & H \\
15 & Pakcoy 5 & H \\
16 & Kale 1 & F \\
17 & Kale 2 & E \\
18 & Kale 3 & F \\
19 & Kale 4 & F \\
20 & Kale 5 & E \\
\hline
\end{tabular}

Tabel 5 merupakan hasil pengujian dengan berbagai input image resizer dan berbagai jarak antara objek dengan handphone yang diambil secara realtime. Input image yang dimaksud di sini adalah saat men-generate model ke tflite. Keterangan kolom pada tabel hasil pengujian Tabel 5 untuk hasil realtime adalah sebagai berikut:
$5=$ Jarak $5 \mathrm{~cm}$
$10=$ Jarak $10 \mathrm{~cm}$
$15=$ Jarak $15 \mathrm{~cm}$
$20=$ Jarak $20 \mathrm{~cm}$ 
Tabel 5. Hasil Pengujian Aplikasi

\begin{tabular}{|c|c|c|c|c|c|c|c|c|c|c|c|c|c|c|c|c|}
\hline \multirow[t]{2}{*}{ Gambar } & $320 \times 320$ & \multicolumn{14}{|c|}{ Pengujian } & $1024 \times 1024$ \\
\hline & 5 & 10 & 15 & 20 & 5 & 10 & 15 & 20 & 5 & 10 & 15 & 20 & 5 & 10 & 15 & 20 \\
\hline 1 & $\mathrm{~A}$ & $\mathrm{~A}$ & $\mathrm{~A}$ & $\mathrm{~A}$ & $\mathrm{~A}$ & $\mathrm{G}$ & $\mathrm{G}$ & $\mathrm{A}$ & $\mathrm{A}$ & $\mathrm{A}$ & $\mathrm{A}$ & $\mathrm{A}$ & $\mathrm{B}$ & $\mathrm{A}$ & B & $\mathrm{B}$ \\
\hline 2 & A & A & $\mathrm{B}$ & $\mathrm{A}$ & A & $\mathrm{G}$ & G & $\mathrm{G}$ & A & A & A & A & $\mathrm{B}$ & $\mathrm{G}$ & $\mathrm{G}$ & A \\
\hline 3 & A & A & $\mathrm{A}$ & $\mathrm{A}$ & A & A & A & A & A & A & A & A & A & B & B & B \\
\hline 4 & B & A & $\mathrm{A}$ & A & A & A & G & $\mathrm{H}$ & A & A & A & G & $\mathrm{F}$ & $\mathrm{F}$ & B & B \\
\hline 5 & B & B & $\mathrm{A}$ & $\mathrm{B}$ & $\mathrm{G}$ & $\mathrm{H}$ & $\mathrm{H}$ & $\mathrm{H}$ & B & B & B & $\mathrm{B}$ & B & B & G & $\mathrm{G}$ \\
\hline 6 & $\mathrm{C}$ & $\mathrm{C}$ & $\mathrm{D}$ & $\mathrm{D}$ & $\mathrm{D}$ & $\mathrm{D}$ & $\mathrm{D}$ & $\mathrm{D}$ & $\mathrm{D}$ & $\mathrm{D}$ & $\mathrm{D}$ & $\mathrm{D}$ & $\mathrm{D}$ & $\mathrm{D}$ & $\mathrm{D}$ & $\mathrm{D}$ \\
\hline 7 & $\mathrm{C}$ & $\mathrm{C}$ & $\mathrm{C}$ & $\mathrm{C}$ & $\mathrm{C}$ & $\mathrm{C}$ & $\mathrm{C}$ & $\mathrm{C}$ & $\mathrm{C}$ & $\mathrm{C}$ & $\mathrm{C}$ & $\mathrm{C}$ & D & $\mathrm{C}$ & $\mathrm{D}$ & D \\
\hline 8 & $\mathrm{C}$ & $\mathrm{C}$ & $\mathrm{C}$ & $\mathrm{C}$ & $\mathrm{C}$ & $\mathrm{C}$ & $\mathrm{C}$ & $\mathrm{C}$ & $\mathrm{C}$ & $\mathrm{C}$ & $\mathrm{C}$ & $\mathrm{C}$ & $\mathrm{C}$ & $\mathrm{C}$ & $\mathrm{C}$ & $\mathrm{C}$ \\
\hline 9 & $\mathrm{C}$ & $\mathrm{C}$ & $\mathrm{C}$ & $\mathrm{C}$ & $\mathrm{C}$ & $\mathrm{C}$ & $\mathrm{C}$ & $\mathrm{C}$ & $\mathrm{C}$ & $\mathrm{C}$ & D & $\mathrm{C}$ & $\mathrm{D}$ & $\mathrm{D}$ & $\mathrm{D}$ & $\mathrm{D}$ \\
\hline 10 & $\mathrm{D}$ & D & $\mathrm{D}$ & D & $\mathrm{C}$ & $\mathrm{C}$ & $\mathrm{D}$ & $\mathrm{C}$ & $\mathrm{C}$ & $\mathrm{C}$ & $\mathrm{C}$ & $\mathrm{C}$ & $\mathrm{D}$ & $\mathrm{D}$ & $\mathrm{D}$ & $\mathrm{D}$ \\
\hline 11 & $\mathrm{H}$ & $\mathrm{H}$ & $\mathrm{H}$ & $\mathrm{H}$ & $\mathrm{H}$ & $\mathrm{H}$ & $\mathrm{H}$ & $\mathrm{H}$ & $\mathrm{H}$ & $\mathrm{H}$ & $\mathrm{G}$ & $\mathrm{G}$ & $\mathrm{H}$ & $\mathrm{H}$ & $\mathrm{H}$ & $\mathrm{H}$ \\
\hline 12 & $\mathrm{G}$ & $\mathrm{G}$ & $\mathrm{G}$ & $\mathrm{G}$ & $\mathrm{G}$ & $\mathrm{H}$ & $\mathrm{G}$ & $\mathrm{G}$ & $\mathrm{G}$ & $\mathrm{G}$ & $\mathrm{G}$ & $\mathrm{G}$ & $\mathrm{G}$ & $\mathrm{H}$ & $\mathrm{H}$ & $\mathrm{G}$ \\
\hline 13 & $\mathrm{G}$ & $\mathrm{G}$ & $\mathrm{G}$ & $\mathrm{H}$ & $\mathrm{G}$ & $\mathrm{G}$ & $\mathrm{H}$ & $\mathrm{D}$ & $\mathrm{G}$ & $\mathrm{G}$ & $\mathrm{G}$ & $\mathrm{G}$ & $\mathrm{G}$ & $\mathrm{G}$ & $\mathrm{G}$ & $\mathrm{G}$ \\
\hline 14 & $\mathrm{H}$ & $\mathrm{H}$ & $\mathrm{H}$ & $\mathrm{G}$ & $\mathrm{H}$ & $\mathrm{H}$ & $\mathrm{H}$ & E & $\mathrm{H}$ & $\mathrm{H}$ & $\mathrm{H}$ & $\mathrm{H}$ & $\mathrm{G}$ & $\mathrm{H}$ & $\mathrm{H}$ & $\mathrm{H}$ \\
\hline 15 & $\mathrm{H}$ & $\mathrm{H}$ & $\mathrm{H}$ & $\mathrm{H}$ & $\mathrm{H}$ & $\mathrm{H}$ & $\mathrm{H}$ & $\mathrm{H}$ & $\mathrm{H}$ & $\mathrm{H}$ & $\mathrm{H}$ & $\mathrm{H}$ & $\mathrm{G}$ & $\mathrm{H}$ & $\mathrm{H}$ & $\mathrm{H}$ \\
\hline 16 & $\mathrm{~F}$ & $\mathrm{~F}$ & $\mathrm{E}$ & $\mathrm{F}$ & $\mathrm{F}$ & $\mathrm{F}$ & $\mathrm{F}$ & $\mathrm{F}$ & $\mathrm{F}$ & $\mathrm{F}$ & $\mathrm{F}$ & $\mathrm{F}$ & $\mathrm{E}$ & $\mathrm{F}$ & $\mathrm{F}$ & $\mathrm{F}$ \\
\hline 17 & $\mathrm{E}$ & $\mathrm{E}$ & $\mathrm{E}$ & $\mathrm{E}$ & $\mathrm{E}$ & $\mathrm{E}$ & $\mathrm{E}$ & E & $\mathrm{E}$ & $\mathrm{E}$ & $\mathrm{E}$ & $\mathrm{E}$ & $\mathrm{F}$ & $\mathrm{E}$ & $\mathrm{E}$ & $\mathrm{E}$ \\
\hline 18 & $\mathrm{~F}$ & $\mathrm{~F}$ & $\mathrm{~F}$ & $\mathrm{~F}$ & $\mathrm{~F}$ & $\mathrm{~F}$ & $\mathrm{~F}$ & $\mathrm{~F}$ & $\mathrm{~F}$ & $\mathrm{~F}$ & $\mathrm{~F}$ & $\mathrm{~F}$ & $\mathrm{~F}$ & $\mathrm{~F}$ & $\mathrm{~F}$ & $\mathrm{~F}$ \\
\hline 19 & $\mathrm{~F}$ & $\mathrm{~F}$ & $\mathrm{~F}$ & $\mathrm{~F}$ & $\mathrm{~F}$ & $\mathrm{~F}$ & $\mathrm{~F}$ & $\mathrm{~F}$ & $\mathrm{~F}$ & $\mathrm{~F}$ & $\mathrm{~F}$ & $\mathrm{~F}$ & $\mathrm{~F}$ & $\mathrm{~F}$ & $\mathrm{~F}$ & $\mathrm{~F}$ \\
\hline 20 & $\mathrm{E}$ & $\mathrm{E}$ & $\mathrm{E}$ & $\mathrm{E}$ & $\mathrm{E}$ & $\mathrm{E}$ & $\mathrm{E}$ & $\mathrm{F}$ & $\mathrm{E}$ & E & E & $\mathrm{E}$ & $\mathrm{F}$ & $\mathrm{E}$ & $\mathrm{F}$ & $\mathrm{F}$ \\
\hline
\end{tabular}

Dari Tabel 5 hasil uji kemudian dihitung nilai akurasinya selesai dan didapatkan nilai dari TP, TN, FP, dan FN menggunakan persamaan (2). Dengan memperhatikan maka dilakukan perhitungan akurasi dengan persamaan keterangan yang ada persamaan (2), dapat (2). Hasil dari perhitungan akurasi dapat digambarkan membandingkan antara Tabel 4 dan Tabel 5 untuk dalam grafik yang tersaji Gambar 6. mengetahui TP, TN, FP, dan FN. Setelah perbandingan

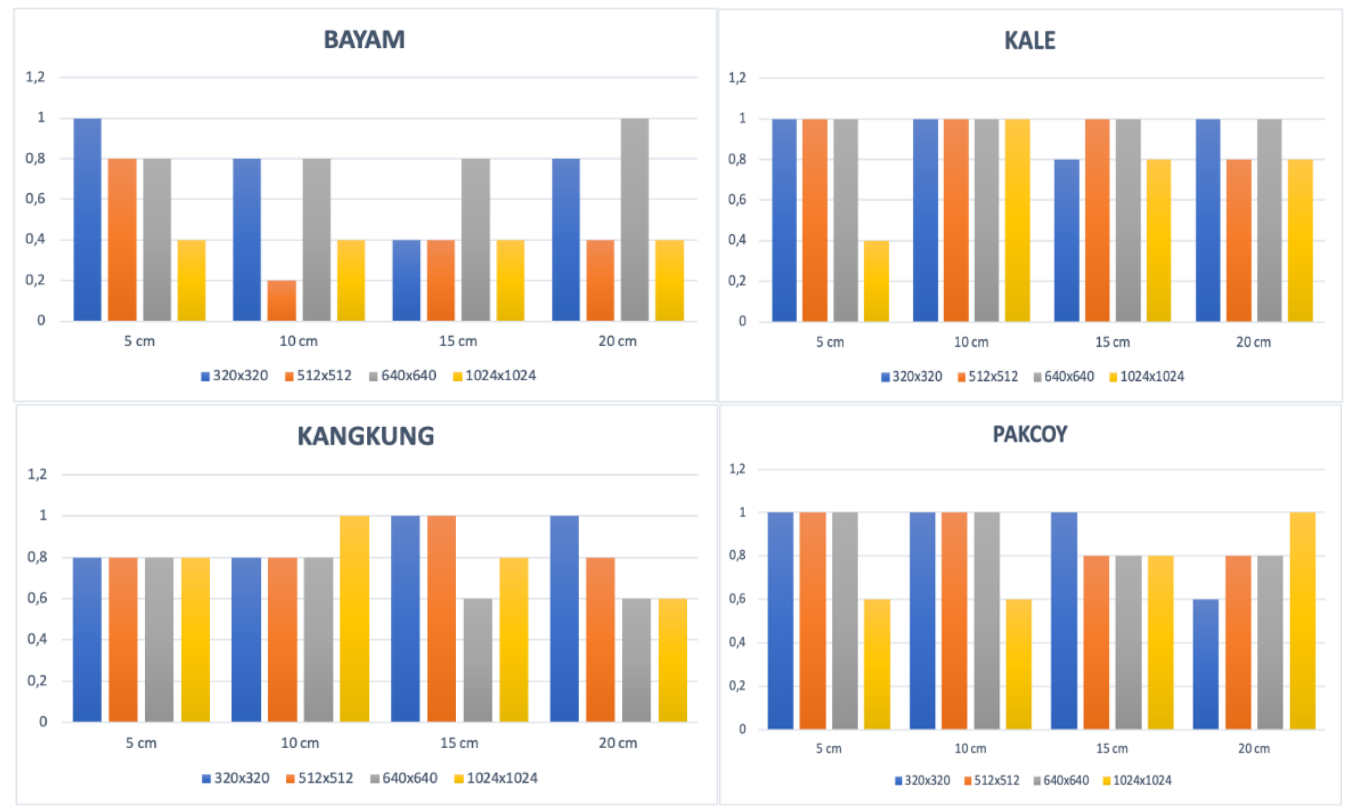

Gambar 6. Grafik Hasil Akurasi

Gambar 6 terlihat grafik hasil perhitungan akurasi di seperti Gambar 6 kemudian dicari total akurasi dengan setiap tanaman sayuran yaitu bayam, kale, kangkung, dan menjumlahkan akurasi di tiap tanaman dengan input pakcoy, hasil uji coba aplikasi android object detection yang sama dan jarak pengujian yang sama. Misalkan masa siap panen pada tanaman sayuran dengan skenario untuk input 320 x 320 dengan jarak pengujian $5 \mathrm{~cm}$ realtime atau mengambil gambar secara langsung adalah akurasi bayam + akurasi kale + akurasi kangkung melalui kamera ponsel android dengan jarak $5 \mathrm{~cm}, 10 \mathrm{~cm}$, + akurasi kangkung + akurasi pakcoy $=1+1+0,8+1=$ $15 \mathrm{~cm}$, dan $20 \mathrm{~cm}$ serta input $320 \times 320,512 \times 512,640$ 3,8. Hasil perhitungan dari keseluruhan tersaji dalam x 640 dan 1024 x 1024 sesuai dengan pelatihan model. Tabel 6. Tabel 6 merupakan hasil dari penjumlahan Setelah mengetahui nilai akurasi dari tiap tanaman akurasi keempat tanaman sayuran di tiap input dan jarak

DOI: https://doi.org/10.29207/resti.v5i4.3190

Lisensi: Creative Commons Attribution 4.0 International (CC BY 4.0) 
pengujian, jumlah akurasi keseluruhan, jumlah $\mathrm{cm}$ dengan skor 13,2 dari hasil perhitungan total akurasi pembagian dari jumlah akurasi keseluruhan dengan di tiap input.

jumlah data dan total akurasi tiap jarak pengujian.

Tabel 6. Total Akurasi

\begin{tabular}{lllllll}
\hline Input & $\begin{array}{l}5 \\
\mathrm{~cm}\end{array}$ & $\begin{array}{l}10 \\
\mathrm{~cm}\end{array}$ & $\begin{array}{l}15 \\
\mathrm{~cm}\end{array}$ & $\begin{array}{l}20 \\
\mathrm{~cm}\end{array}$ & $\begin{array}{l}\text { Jumlah } \\
\text { akurasi }\end{array}$ & $\begin{array}{l}\text { Jumlah } \\
\text { akurasi } \\
\text { jumlah data }\end{array}$ \\
\hline 320 & 3,8 & 3,6 & 3,2 & 3,4 & 14 & 0,7 \\
512 & 3,6 & 3 & 3,2 & 2,8 & 12,6 & 0,63 \\
640 & 3,6 & 3,6 & 3,2 & 3,4 & 13,8 & 0,69 \\
1024 & 2,2 & 3 & 2,8 & 2,8 & 10,8 & 0,54 \\
Total & 13,2 & 13,2 & 12,4 & 12,4 & & \\
\hline
\end{tabular}

Tabel 6 terdapat kolom jumlah akurasi/ jumlah data, jumlah data yang dimaksud adalah 20 data pengujian. Dari kolom tersebut dapat diketahui input yang bagus dalam mendeteksi masa siap panen pada tanaman sayuran secara realtime adalah 320 x320 dengan nilai akhir adalah 0,7 sedangkan input yang kurang bagus dalam mendeteksi masa siap panen adalah 1024 x1024 memiliki nilai akhir adalah 0,54 .

Dalam menentukan jarak ideal dapat merujuk Tabel 6 yang disajikan pada total. Total yang ada pada Tabel 6 merupakan hasil penjumlahan setiap input, dengan nilai yang tertinggi pada total dapat dijadikan sebagai jarak ideal yaitu nilai 13, 2 yang terdapat pada jarak $5 \mathrm{~cm}$ dan $10 \mathrm{~cm}$ sehingga jarak ideal dalam mendeteksi masa siap panen pada tanaman sayuran adalah jarak $5 \mathrm{~cm}$ dan 10 $\mathrm{cm}$.

\section{Kesimpulan}

Kesimpulan yang dapat diperoleh dari hasil penelitian mengenai deteksi objek untuk masa siap panen pada tanaman sayuran dengan data 36.000 data latih dan 4.000 data uji, pelatihan model dengan konfigurasi SSD Mobilenet v3 large dengan image resizer 320 × 320, 512 x 512, 640 x 640, dan 1024 x 1024 menghasilkan nilai MAP tertinggi adalah 0,705510 evaluasi dengan image resizer 320 x 320, dan MAP terendah adalah 0,652937 evaluasi dengan image resizer 1024 x 1024. Pengujian 20 gambar dengan aplikasi android yang dibangun diperoleh nilai akurasi tertinggi adalah 0,7 pada pengujian input 320 x 320, yang menandakan bahwa aplikasi android yang dikembangkan dapat mendeteksi dengan baik sedangkan nilai terendah akurasinya adalah 0,54 pada pengujian dengan input 1024 x 1024 yang berarti kurang baik dalam mendeteksi masa siap panen pada tanaman sayuran. Hasil evaluasi dan hasil pengujian aplikasi android yang dikembangkan memiliki kesamaan tingkat tinggi rendahnya nilai MAP hasil evaluasi dan nilai akurasi diperoleh dari pengujian aplikasi yaitu 0,7 atau $70 \%$.

Dari pengujian 20 gambar, jarak ideal untuk mendapatkan hasil yang bagus dalam mendeteksi masa siap panen pada tanaman sayuran khususnya bayam, kale, kangkung dan pakcoy dengan menggunakan aplikasi yang dikembangkan adalah jarak $5 \mathrm{~cm}$ dan 10
Pengembangan lebih lanjut dalam aplikasi deteksi objek untuk masa siap panen pada tanaman sayuran, perlu memperhatikan ukuran gambar dan gambar hanya memiliki satu objek saja misalkan tanaman bayam yang belum siap panen saja atau tanaman bayam siap panen saja agar hasil yang didapatkan sesuai dan lebih tepat. Penelitian selanjutnya dapat menggunakan arsitektur lain untuk membandingkan dengan hasil yang peneliti kembangkan.

\section{Daftar Rujukan}

[1] Supristiwendi and M.Azizah, "Pengaruh Penerapan Sistem Agribisnis Terhadap Pendapatan Usahatani Mentimun (cucumis sativus 1.) Di Kecamatan Rantau Kabupaten Aceh Tamiang", $J$. Penelitian Agrisamudra, vol. 6, no. 2,: pp. 95-103, 2019, doi: 10.33059/jpas.v6i2.244.

[2] Anonim, "Hidroponik Sayuran Ningrat", www.trubusonline.co.id, 2016, [Online]. Available: https://www.trubusonline.co.id/hidroponik-sayuran-ningrat/.

Anonim, "Berapa Umur Sayuran Siap Panen? 10 Jenis Sayuran Ini Paling Cepat Panen!", klikhijau.com, 2020, [Online], Available: https://klikhijau.com/read/berapa-umur-sayuransiap-panen-10-jenis-sayuran-ini-paling-cepat-panen/.

[4] Ichwan, M., Dewi, I. A., and S, Zeni. M, "Klasifikasi Support Vector Machine (SVM) Untuk Menentukan Tingkat Kemanisan Mangga Berdasarkan Fitur Warna", MIND Journal, vol. 3 no. 2, pp. 16-23, 2019, doi: 10.26760/mindjournal.v3i2.

[5] Marifatul Azizah, L., Fadillah Umayah, S., and Fajar, F, "Deteksi Kecacatan Permukaan Buah Manggis Menggunakan Metode Deep Learning dengan Konvolusi Multilayer", Semesta Teknika, vol. 21 no. 2, pp. 230-236, 2018, doi: 10.18196/st.212229

Marlinda, R, "Cara Panen Pakcoy", riska2011611048.blogspot.com, 2018, [Online]. Available: http://riska2011611048.blogspot.com/2018/03/cara-panenpakcoy.html\#: :text=Syarat Panen Pakcoy \%3A,ketinggian tanaman seragam dan merata.

Nofita, V, "Panen Kangkung Lama? Kata Siapa Siihhhh....", www.pulokambing.com, 2018, [Online]. Available: https://www.pulokambing.com/panen-kangkung-lama-katasiapa-siihhhh/.

[8] Permadi, Y., and Murinto, "Aplikasi Pengolahan Citra Untuk Identifikasi Kematangan Mentimun Berdasarkan Tekstur Kulit Buah Menggunakan Metode Ekstraksi Ciri Statistik", J. Informatika, vol. 9 no. 1, pp. 1028-1038, 2015, doi: 10.26555/jifo.v9i1.a2044.

Pratama, R., Assagaf, A. F., and Tempola, F., "Menggunakan Metode Transformasi Ruang Warna His Tomato Fruit Detection Detection Based On Color Features Using His Color Space Transformation Method", JIKO (Jurnal Informatika dan Ilmu Komputer), vol. 2 no. 2, pp. 81-86, 2019, doi: 10.33387/jiko.

10] Rianto, P., and Harjoko, A, "Penentuan Kematangan Buah Salak Pondoh Di Pohon Berbasis Pengolahan Citra Digital", IJCCS (Indonesian Journal of Computing and Cybernetics Systems), vol. 11 no. 2, pp. 143-154, 2017, doi: 10.22146/ijccs. 17416 .

[11] Sa, I., Ge, Z., Dayoub, F., Upcroft, B., Perez, T., and McCool, C, "Deepfruits: A fruit detection system using deep neural networks", Sensors, vol. 16 no. 8, pp. 1222, 2016, doi: $10.3390 / \mathrm{s} 16081222$.

[12] Septiaji, K. D., and Firdausy, K, "Deteksi Kematangan Daun Selada (Lactuca Sativa L) Berbasis Android Menggunakan Nilai RGB Citra", J. Ilmiah Teknik Elektro Komputer Dan Informatika, vol. 4 no. 1, pp. 20-27, 2018, doi: 10.26555/jiteki.v4i1.8994. 
[13] Widito, Y, "Cara Menanam Bayam Yang Benar", [20] Prabowo, H, "Deteksi Kondisi Kematangan Buah Jeruk kutanam.com, 2020, [Online]. Available: Berdasarkan Kemiripan Warna Pada Ruang Warna RGB https://kutanam.com/cara-menanam-bayam-yang-benar/.

[14] Sharpe, Shaun and Schumann, Arnold and Yu, Jialin and Boyd, Nathan, "Vegetation detection and discrimination within vegetable plasticulture row-middles using a convolutional neural network", Precision Agriculture, vol. 21, pp. 264-277, 2020, doi: 10.1007/s11119-019-09666-6.

[15] Kuznetsova, A., Maleva, T., and Soloviev, V, "Using YOLOv3 Algorithm with Pre- and Post-Processing for Apple Detection in Fruit-Harvesting Robot", Agronomy, vol. 10 no. 7, pp. 1016, 2020, doi: 10.3390/agronomy10071016.

[16] Sreekanth, G., Thangaraj, P., and Kirubakaran, S, "Fruit Detection Using Improved K-Means Algorithm", Journal of Critical Reviews, vol. 7 no. 12, pp. 5-6, 2020, doi: 10.31838/jcr.07.12.02

[17] Nishi, T., Kurogi, S., and Matsuo K, "Grading Fruits and Vegetables Using RGB-D Images and Convolutional Neural Network", IEEE SSCI (Symposium Series on Computational Intelligence), pp. 1-6, 2017, doi: 10.1109/SSCI.2017.8285278.

[18] Qimei Wang, Feng Qi, Minghe Sun, Jianhua Qu, and Jie Xue, [25] "Identification of Tomato Disease Types and Detection of Infected Areas Based on Deep Convolutional Neural Networks and Object Detection Techniques", Computational Intelligence and Neuroscience, vol. 2019, pp. 1-15, 2019. doi: 10.1155/2019/9142753.

[19] Akbar, M., Sardjono, M., Cahyanti, M., and Swedia, E, "Perancangan Aplikasi Mobile Untuk Klasifikasi Sayuran Menggunakan Deep Learning Convolutional Neural Network", SEBATIK, vol. 24 no. 2, pp. 300-306, 2020, doi: 10.46984/sebatik.v24i2.1134.

Berbasis Android", JESIK (Jurnal Elektronik Sistem Informasi dan Komputer), vol. 3 No. 2, 2017.

[21] Yesiansyah, and Murinto, "Aplikasi Deteksi Kematangan Buah Sawit Menggunakan Metode Perbandingan Histogram Citra", JSTIF (Jurnal Sarjana Teknik Informatika), vol. 4 no. 3, 2016, doi: 10.12928/jstie.v4i3.10796.

[22] Indarto and Murinto, "Deteksi Kematangan Buah Pisang Berdasarkan Fitur Warna Citra Kulit Pisang Menggunakan Metode Transformasi Ruang Warna HIS", JUITA, vol. 5 no. 1, pp.15-21, 2017, doi: 10.30595/juita.v5i1.1461.

[23] Yogi, M., "Aplikasi Deteksi Kematangan Buah Semangka Berbasis Nilai RGB Menggunakan Metode Thresholding", JURIKOM, vol. 3 no. 6, pp. 84-89, 2016, doi: 10.30865/jurikom.v3i6.179.

[24] Asshiddiqie, M., Rahmat, B. and Anggraeny, F., "Deteksi Tanaman Tebu Pada Lahan Pertanian Menggunakan Metode Convolutional Neural Network", JIFoSi, vol. 1 no. 1, pp. 229237, 2020.

[25] Maulana, F., and Rochmawati, N., "Klasifikasi Citra Buah Menggunakan Convolutional Neural Network", JINACS, vol. 01 no. 02 , pp. 104-108, 2019. 